ISSN 2519-2523 (print)

Chornomors'ka mynuvshyna. - 2020. - No.15

DOI: $10.18524 / 2519-2523.2020 .15 .218681$

УДК 94(71=161.2)

\title{
SOCIO-CULTURAL MISSION OF THE CANADIAN UKRAINIAN CULTURAL AND EDUCATIONAL CENTER «OSEREDOK» (second quarter of 20th - beginning of 21st century)
}

\author{
Anatoliy Bodrug \\ ORCID: https://orcid.org/0000-0001-6718-4957 \\ Post-graduate student \\ of the Department of History of Ukraine \\ Odessa I. I. Mechnikov National University \\ 2, Dvoryanska Str., Odessa, 65082, Ukraine \\ metall.feniks@yandex.ua
}

The purpose of this article is to consider the activities of the Ukrainian Cultural and Educational Center "Oseredok» and the theoretical justification of its contribution to the collection, research, preservation and exhibition of historical, cultural and spiritual heritage of the Ukrainian diaspora in Canada. "Oseredok» became not only a model of Ukrainian studies education, but also an important center for the development of Ukrainian-Canadian relations, and also influenced the development of Canadian culture in general. To achieve this goal, the necessary number of sources and historiographical literature touched on various aspects of the problem were examined. Such general historical scientific research methods as historical-genetic, historical-comparative and historical-typological were used.

The relevance of this study is related to the modern national-cultural movement, which is embodied in the activities of organizations, art, educational and scientific centers, the introduction of new Ukrainian festivals, the study of previously classified, archival documents. Some aspects of this problem were revealed in the works of such researchers as: Jus O. V., Matyash I. B., Solonskaya N. G. and Priymak T. M. However, in our opinion, the monument protection and sociocultural activities of the Ukrainian Cultural and Educational Center «Oseredok» is worth more indepth research.

Thus, the Ukrainian Cultural and Educational Center "Oseredok» was the unifying force that brought together under one cultural cover Ukrainians with different religious beliefs, political views and values. The founders and patrons of the "Oseredok» were prominent Ukrainian figures: O. Koshetz, T. Koshetz, P. Matsenko, M. Mandryka, T. Pavlychenko, P. Yuzyk, V. Kossar, M. Marunchak, J. Rudnytsky and others. For 76 years, Oseredok has become the guarantor of the collective memory of the Ukrainian people. Even the house of the organization, formerly the House of the Bible Society, has great spiritual power, which contributes to a noble socio-cultural mission. The versatility of the Center's activities, which includes archival, library, museum, educational and publishing work, is striking. The archive of the organization has the largest collection of documents, memoirs, photographs, maps in Canada, which covers the period of 16th - 20th centuries. Valuable are the documents and memoirs of I. M. Bobersky, E. M. Konovalets, the Koshets family, as well as a monument of the 18th century - Irmola by Georgy Tyapetsky. "Oseredok» has a rich library collection of more than 40 thousand volumes and 10 thousand periodicals. Nomocanon of the 17th century is a very rare book. The collection of the museum of the Center consists of 8 thousand exhibits, which includes objects of decorative and applied arts, musical instruments, church utensils, personal belongings. In the collections of the art gallery you can see paintings by more than 30 Ukrainian artists from realism to avant-garde. The Center has higher education courses that have brought up many prominent Ukrainians. The publishing activity 
of the center not only contributed to the development of science and art, but also acquainted the whole world with the rich Ukrainian culture. Thus, Ukrainian Cultural and Educational Centre «Oseredok» is a model of cultural preservation organization.

Key words: Ukrainian diaspora of Canada, The Ukrainian Cultural and Educational Center «Oseredok», The Ukrainian National Federation of Canada (U.N.F.), Ukrainian studies, archival studies.

\section{СОЦІОКУЛЬУРНА МІСІЯ КАНАДСЬКОГО ЦЕНТРУ УКРАЇНСЬКОЇ КУЛЬТУРИ ТА ОСВІТИ «ОСЕРЕДОК» (друга чверть ХХ - початок XXI ст.)}

Мета даної наукової статті полягає у розгляді діяльності Центру української культури та освіти «Осередок» та теоретичного обтрунтування його внеску у процеси збирання, дослідження, збереження та подальшого експозиціонування історичної, культурної та духовної спадщини украӥнської діаспори Канади. Саме об'єднання зусиль суспільно-політичних організачій та відомих громадських діячів заклало важливу підвалину в збереження нації в тяжких воєнних та соціальних умовах перебування на чужині. «Осередок» став не лише взірием украӥнознавчої освіти, але і важливим центром розбудови українсько-канадських відносин, а також загалом вплинув на розвиток канадської культури. Для досягнення зазначеної мети було залучено необхідну кількість джерел та історіографічної літератури, які торкались різних аспектів проблеми. Автором було застосовано такі загальноісторичні наукові методи дослідження, як історико-генетичний, історико-порівняльний та історико-типологічний. У межах даного дослідження було надано генезис Центру украӥнської культури та освіти «Осередок», розглянуто основні підрозділи, напрямки роботи, сочіокультурні програми, типологізовано найважливіші колекції й архівні документи, а також проаналізовано їх історико-культурну иінність. Окрема увага присвячена аналізу ролі засновників, збирачів колекцій та меценатів $у$ розвитку «Осередку». Вперше здійснена спроба узагальнення різних аспектів порушеної проблеми.

Ключові слова: украӥнська діаспора Канади, Центр украӥнської культури та освіти «Осередок», Украӥнське Національне Об'єднання (УНО), украӥнознавство, архівознавство.

«Осередок - місце для всіх українців, де для одної дорогої всіх цілі можуть працювати всі разом, без поділів за переконанням і релігійною приналежності, а як діти одного народу, який має одну велику, людяну й героїчну історію та одну красну й своєрідну культуру» [7, с. 1] - відзначав талановитий поет, видатний науковець, громадсько-політичний та культурний діяч, голова Центру української культури та освіти «Осередок» у 1950-1958 рр. Тиміш Павличенко. У даний вислів вкладено глибокий культурологічний та етнополітологічний зміст, основні аспекти яких чітко прослідковуються в історичному процесі українського народу. I дійсно, у вирі бурхливих революційних подій або у роки тяжкого воєнного лихоліття збереження кожної нації залежало від колективного усвідомлення важливості об'єднання народу в єдину та цілісну громаду. Історичний досвід свідчить, що ідеологічний або релігійний розбрат викликав культурний занепад, етнічну асиміляцію та зникнення 
цілих держав з політичної карти світу. Так, у X-XIII ст. воєнні кампанії русичів проти степових кочівників були успішними лише тоді, коли слов'янські народи виступали об'єднаним військом. Проте феодальна роздробленість та міжусобні війни не дали змогу вистояти у XIII ст. перед татаро-монгольською навалою, що призвело до остаточного занепаду могутньої Київської Русі. В XV-XVIII ст. на чолі збереження національної культури виступило славне українське козацтво, яке відрізнялось воєнною доблестю, оригінальною стратегією та чудовою злагодженістю. Але вже у другій пол. XVII ст. в козацькій громаді почав набирати обертів релігійно-політичний розбрат та сепаратистські тенденції, які стали причиною громадянської війни. Наслідком Руїни став поділ України між сусідніми державами Річчю Посполитою та Московією. 3 кінця XVIII - XIX ст. зароджується новий соціокультурний феномен український національний рух, який заклав основу у майбутню українську революцію та створення УНР. Важливою складовою данного руху було відродження національної культури, збір та обробка фольклорних пам'яток, розвиток мистецтва, відкриття цілої низки організацій, які проводили значну громадську, культурну, релігійну та політичну роботу, спрямовану на пропаганду патріотичної думки. Після фактичної поразки Директорії УНР у 1920 р. внаслідок непослідовних внутрішньо- та зовнішньополітичних рішень, розбіжностей у поглядах урядовців, втрати довіри 3 боку населення, розгрому у війні з більшовиками, діяльність багатьох українських націоналістичних організацій не припинили свою роботу, а реорганізувались та змінили місця своєї дислокації. Майже напередодні Другої світової війни 18 січня 1939 р. колишніми членами УНР та громадсько-культурними діячами Підкарпатської Русі у м. Хуст було засновано нову політичну організацію - Українське національне об'єднання (УНО). Ідеологічно і політично черпала ця організація свої соки 3 українського націоналістичного руху, який очолював полковник Евген Коновалець [3, c. 136]. Головною метою організації стало відстоювання інтересів українського народу, збереження історичної та культурної ідентичності у Карпатській Україні, як автономному краї Чехословацької республіки. Проте у березні 1939 р. Закарпаття було анексовано Угорським королівством, що стало причиною згортання діяльності УНО на цій території, що, однак, не означало остаточного припинення іiі роботи. Діяльність організації була продовжена за океаном, а саме на території Канади, де перший підрозділ УНО було відкрито в Едмонтоні ще в 1932 р. У 1943 р. філію УНО було відкрито в столиці провінції Манітоба - м. Вінніпег. Саме представники Українського національного об'єднання, а також видатні культурні, наукові, громадські, політичні діячі та всі небайдужі члени української діаспори згуртувались довкола націєоб'єднуючої мети і виступили засновниками та фундаторами Центру української культури та освіти «Осередок» (The Ukrainian Cultural and Educational Centre «Oseredok»).

Актуальність даного дослідження пов'язана з сучасним національно-культурним рухом, що втілюється в розгортанні діяльності широкого кола організацій, спілок, мистецьких, освітніх та наукових центрів, запровадженні нових українських фестивалів та освітньо-культурних проектів, відкритті та дослідженні, раніше засекречених, архівних документів як на етнічній території, так і в осередках української діаспори Канади.

Окремі аспекти даної проблеми були розкриті в працях таких дослідників, як: Джус О. В. [2], Матяш І. Б. [4; 5; 6], Солонська Н. Г. [10; 11] і Приймак Т. М. [12]. Проте, на наш погляд, пам'яткоохоронна та соціокультурна діяльність Центру української культури та освіти «Осередок» варта більш глибокого наукового 
дослідження. Наразі досить важливою справою є дослідження культурних артефактів, архівних матеріалів, розгляд наукових, освітніх, фольклорних та мистецьких проектів «Осередку», а також аналіз діяльності громадсько-політичних діячів, членів Українського національного об'єднання, митців та науковців, які виступили у ролі засновників центру, сприяли його розвитку та зробили вагомі внески у поповнення його коштовних колекцій.

Станом на початок Другої світової війни тривала друга хвиля української імміграції до Канади. Проте через воєнні обмеження та бюрократичні перепони у 1941 p. процеси переселення практично припинились. Перебуваючи у складі Британської співдружності, Канадський домініон вступив у війну 10 вересня 1939 р. Держава в цей час переживала далеко не кращу підготовку, що було пов'язано передовсім зі станом економіки, сильно виснаженої від наслідків Великої депресії, слабкої, малочисельної, погано оснащеної армії, антимобілізаційних настроїв населення, особливо у провінції Квебек. Політична криза назрівала також і через невдалі виступи у війні, багаточисленні втрати армії, яка налічувала 1,1 млн. канадців, з них близько 30 тис. українців. Ситуація покращилась тільки в 1944 р. в ході Нормандської операції, коли канадські війська гідно виступили у бою за звільнення Нідерландів. До того ж військові замовлення сприяли інтенсивній індустріалізації та зростанню економіки держави. Вагомий внесок у даний процес зробила і українська діаспора, представники якої не тільки займали різні щаблі армії від рядових до офіцерів, але і працювали на військових підприємствах, у науководослідних центрах, де розробляли нові види оборонного та наступального озброєння. У цей тяжкий для українців час, як ніколи раніше, постала потреба у міцній консолідації, збереженні та примноженні культурної ідентичності. Ті пам’ятки, що були поза межами України - в Берліні (Архів Української установи «Довір'я»), Парижі (Книгозбірня ім. С. Петлюри), Празі (Український Музей) і Варшаві, німці повивозили. Більшість із них зникла безслідно. В Україні такі інституції розграбовували або нищили. По розгромі збірників українських пам'яток в Свропі не лишилось жодного центру, куди б люди могли надсилати твори постійної вартості на збереження [13, с. 3-4]. Отже, відчувалась нагальна потреба у відкритті нової установи, яка б виконувала пам'яткозберігаючу та дослідницьку роль. В 1943 р. за сприяння УНО, а також відомого історика і політичного діяча П. М. Юзика, композитора, диригента й етнографа О. А. Кошиця, його дружини, відомої співачки Т. О. Кошиць, музикознавця і композитора П. П. Маценка, публіциста і дипломата M. I. Мандрики, поета, члена УВАН і НТШ Т. К. Павличенка та багатьох інших видатних українців в м. Вінніпег було сформовано Громадський комітет для вирішення організаційних питань. 25 березня 1944 р. членами комітету було видано офіційний указ про створення Центру української культури та освіти «Осередок», який об’єднав у собі архів, бібліотеку, музей, мистецьку галерею, видавництво і навчальний заклад. Першим головою «Осередку» став український військовий, громадський діяч, вчений-агроном, член УНО та один із засновників Конгресу українців Канади - Володимир Коссар. Мета нової української інституції полягала в консолідації активних сил задля розвитку української культури й освіти в Канаді, належній репрезентації українських культурних надбань у культурі Канади, досягненні конструктивної співпраці українців з представниками інших етнічних груп Канади й Америки [4, с. 66]. 28 січня 1945 р. в Українському Національному Домі у Вінніпезі відбулися перші збори членів «Осередку», на яких було ухвалено статут та сформульовано основні завдання Центру: 
1) пошук, акумулювання, зберігання, експозиціонування, а також за можливості реставрація витворів мистецтва, виробів народно-ужиткового мистецтва, етнічного одягу, церковного начиння, документів, особистих щоденників, листів, фольклорних і літературних творів, наукових праць, військових і спортивних трофеїв та нагород;

2) адміністрування та організація роботи культурологічного, наукового, освітнього та технічного персоналу закладу;

3) пошук меценатів, залучення інвестицій, збирання пожертв, а також заохочення митців та колекціонерів за спільну соціокультурну діяльність, яка сприятиме різнобічному розвитку «Осередку»;

4) запровадження видавничої діяльності, яка включатиме друк підручників та книжок, спрямованих на культурну просвіту, професійну підготовку молоді i старшого покоління українців Канади;

5) розробка освітніх програм, влаштування суспільних обговорень, конференцій, симпозіумів та введення українознавчих курсів;

6) знайомство канадців інших етнічних груп з українською культурою. Підготовка театральних вистав, хореографічних номерів, концертів, фестивалів, історичних та фольклорних реконструкцій, продукція кіно, видавання української літератури іноземними мовами;

7) матеріальна або інформаційна допомога аналогічним організаціям.

Важливе історичне значення має будівля, в якій знаходиться Центр української культури та освіти «Осередок». На початку своєї роботи під потреби Центру було виділено частину будинку Українського Національного Об'єднання. Проте у зв'язку зі зростанням колекцій та суттєвим розширенням напрямків роботи у другій половині XX ст. площа та якість приміщень вже не задовольняла потреби «Осередку». На початку 1970-х рр. дирекцією Центру було прийнято рішення орендувати для власної бібліотеки 4-й поверх славнозвісної пам'ятки архітектури - будівлі Біблійного товариства, яке було створено в Англії у 1804 р. та мало на меті донесення Слова Божого до «язичників» усього світу. В 1808 р. товариство розпочало свою місію в Канаді, організувавши видання та переклад Біблії на численні мови, копії якої розповсюджувало безкоштовно. Місіонери вважали, що подібні заходи допоможуть іммігрантам налагодити життя на новій землі. Завдяки спільним зусиллям уряду провінції Манітоба, Біблійного товариства та пожертвам простих мирян у 1913 р. було збудовано п’ятиповерхову будівлю, яка охоплювала приміщення для служіння проповіді, недільну школу, їдальню та бібліотеку. На початку Першої світової війни, потік іммігрантів з Європи суттєво зменшився, тому товариство більше не відчувало потребу у такій затишній будівлі. Було прийнято рішення спочатку здати будинок в оренду благодійним організаціям, а потім у 1949 р. взагалі його продати Українській національній видавничій компанії, яка друкувала українознавчу газету «Новий шлях» («New Pathway»). 31950 по 1958 pр. у будівлі також працювали такі спілки, як: Українська національна федерація молоді, Українська асоціація ветеранів війни та Українська жіноча організація. Нарешті, у 1977 р. редакція «Нового шляху» переїхала в інше місце і будинок повністю перейшов у власність «Осередку». Завдяки зусиллям федерального та провінційного урядів, філії УНО, Вінніпезької фундації та української громади було зібрано $\$ 500$ тис., які було витрачено на реконструкцію внутрішнього оздоблення під потреби організації.

В 1944 р. «Осередок» розпочав працю без жодних засобів. Протягом 10 років він провадив постійні зв'язки 3 людьми в Канаді й інших країнах [13, с. 10]. Нині «Осередок» понад усякі надії має великі колекції книжок, документів, рукописів, 
художніх творів, часописів, картин, різьби, вишивок та цінні колекції архівних документів i речей. 3 усіх країв світу постійно надходять нові матеріяли i поповнюють давніше зібрані [9, с. 25-26]. Структурно Центр української культури та освіти «Осередок» містить архів, бібліотеку, музей, галерею, лекторій та видавництво.

Архів «Осередку» має найбільшу в Канаді колекцію українознавчих документів, яка становить понад 2 тис. футів артефактів, пов'язаних 3 різними періодами української історії (XVI-XX ст.), діяльністю державних установ (УНР, ЗУНР), організацій (УНО, ОУН, Комітету Українців Канади, Світової федерації українських політичних в'язнів, Товариства опіки над українськими переселенцями св. Рафаїла та ін.), літературні, публіцистичні, наукові рукописи, листи, партитури та клавіри талановитих співвітчизників (В. К. Авраменка («Українські національні танки, музика і стрій» (1947)), І. М. Боберського («Щоденник» (2003)), Д. К. Гуменної (спогади про Київ, машинописи літературних творів), С. М. Коновальця (документи та часописи «Сурма» (1927-1932) і «Літопис Червоної калини» (1935-1939)), подружжя Кошиців (нотні збірки, «Спогади» (1947-1948) у двох томах), П. П. Маценка (збірки хорових творів), М. І. Мандрики (збірки поезій та наукові праці «Теорія господарської дипломатії» (1934) та ін.), Є. Д. Онацького (мемуари «Сторінки з Римського щоденника» (1920-1943)), С. В. Храпливого («Господарство Холмщини і Підляшшя» (1944)), М. Г. Марунчака («Студії до історії українців Канади» у 5 томах (1964-1980) та ін. роботи), М. Д. Селешка (листи, політичні статі «Націократія», «Три воєнні роки ОУН») та ін. Серед колекцій можна побачити дуже цінний Ірмолой Георгія Тяпецького 1733 р. Крім того, фонди архіву складаються 3 понад 75 тис. фотографій та аудіовізуальних матеріалів, які відтворюють доволі цінну інформацію 3 історії Української революції (1917-1921), внутрішньої та зовнішньої політики УНР, історії еміграції, духовного, наукового, культурного, громадського, економічного, побутового життя української діаспори Канади. Зміну політичного та територіального устрою України 31550 по 1990 рр. чудово ілюструє колекція з понад 350 аркушів географічних карт та близько сотні географічних праць дослідників XVI-XIX ст. У 2005-2006 рр. Архів ОУКО разом 3 Архівами і спеціальними колекціями Манітобського університету та Архівом Саскачеванського університету приєднались до веб-проекту «The Prairie Immigration Experience, 1900-1950» (Досвід імміграції у канадські прерії, 1900-1950) [1, с. 517-518].

«Осередок» має досить багаті бібліотечні фонди, які нараховуют понад 40 тис. томів, близько 10 тис. періодичних видань та понад 400 назв політичних, наукових, духовних, літературних та мистецьких часописів, що публікуються на території Австралії, Канади, США, країн Латинської Америки та Європи. Понад 75 років книгозбірня «Осередку» поповнювалась рідкісними приватними виданнями, досить часто у вигляді подарунків від видатних представників української діаспори Канади: родини Кошиців, П. І. Зварича, Ю. Лісового, П. П. Маценка, В. Климківа, напрочуд цінною є особиста бібліотека Є. М. Коновальця, яку люб'язно передала його дружина О. Федак-Коновалець. Окремі фонди складають книгозбірні українських організацій таких, як: Конгрес українців Канади, Крайова екзекутива УНО, Союз українських канадійських ветеранів тощо. В 1953 р. засновано Відділ рідкісних праць i документів. Сюди входять виключно праці унікального порядку, або ті, яких на ринку неможливо набути [13, с. 10]. Серед рідкісних книг можна виділити Номоканон, який було видано у друкарні Києво-Печерського монастиря у 1624 р. На початку XX ст. унікальну пам'ятку привіз з України до Канади український священник о. Йосафат Жан. Пізніше книгу було подаровано бібліотеці монастиря в оселі Шептицьке, що у 
Квебеку. Внаслідок пожежі у 1938 р. монастир було знищено, але Номоканон було врятовано і до передачі «Осередкові» в 1976 р., він перебував в м. Валь-д'Ор у приватній колекції родини Андрущишиних.

Музей «Осередку» має дуже різноманітну колекцію артефактів в обсязі 8 тис. предметів. Хоча центр було засновано ще в 1944 р., музейний відділ відкрив свої двері відвідувачам тільки в 1951 р., що було пов'язано передусім з проведенням кропіткої роботи з реставрації та класифікації великої кількості цінних експонатів, які українці надсилали як з етнічної території та різних провінцій Канади, так i, загалом, зі всіх куточків нашої планети. Музею «Осередку» належать класичні зразки декоративно-ужиткового мистецтва: писанки, рушники, килими, керамічний посуд, народний одяг з регіональними орнаментами, глибокими символами, ляльки, макети обрядового хліба, хат, керамічні, різьбярські, дерев'яні, ювелірні вироби, побутові та музичні інструменти; церковне начиння: ікони, хрести, посуд, текстильні вироби; військові трофеї, відзнаки, мундири, а також меблі з персональними речами, які належали О. А. Кошицю, С. М. Коновальцю, Р. Р. Гонсету та ін. Експонати музею не тільки допомагають зберегти національну ідентичність, перебуваючи далеко від України, але і знайомлять всіх канадіян, незалежно від расових, мовних відмінностей, релігійних переконань, з багатим духовним та світським світоглядом пересічних українців. В українських артефактах можна простежити еволюційний шлях від старовинних тисячолітніх зразків до витворів сучасних майстрів, які продовжують давні традиції українського народу в Канаді.

Діяльність «Осередку» охоплює також сферу образотворчого мистецтва. В колекціях мистецької галереї можна побачити полотна понад 30 українських художників, які належать до плеяди визначних творців від реалізму XIX ст. до авангардизму XX ст. Загальна кількість робіт сягає понад 750 картин, малюнків, гравюр та ікон, які «Осередок» отримував в дар від самих художників, або викуповував у колекціонерів усього світу. Галерея Центру може похвалитися роботами таких художників, як: К. О. Трутовський (художник-реаліст), О. П. Архипенко (живописець, скульптор-кубіст), О. В. Грищенко (графік, експресіоніст, письменник), М. I. Мороз (автор 3 тис. портретів та пейзажів, пізніше працював в стилі абстрактного експресіонізму), М. М. Левицький (маляр, графік та прозаїк), Я. Я. Гніздовський (графік, кераміст, іконописець), К. Шонк-Русич (художникемаліст, мистецтвознавець, видавець), Я.Сурмач-Міллс (ілюстраторка та вітражистка), а також визначними канадськими митцями українського походження: Я. Майданик (художник, письменник і педагог), І. М. Кейван (графік, живописець, мистецтвознавець, член НТШ), П. М. Куч (художник-карикатурист), В. Д. Курилик (художник і письменник), Д. Стриєк (художник-примітивіст) та багатьох ін. В 1970-х pp. мистецька галерея «Осередку» мала статус найбільшої збірки авангардних робіт у провінції Манітоба. Серед визначних виставок Центру можна згадати ювілейну експозицію робіт українського художника М. М. Левицького, з нагоди 50-річчя його творчої діяльності, яка пройшла в 1985 р. Саме Мирон Левицький підвищив рівень графічного оформлення української книжки в Канаді, завдяки використанню кращих традицій українського народного мистецтва.

При Центрі української культури та освіти «Осередок» діють Вищі освітні курси, які було започатковано ще в 1940 р., завдяки широкій патріотичній та благодійній роботі УНО, а також залученні педагогів та священників, які не тільки сповідували різні релігійні та політичні погляди, але і працювали на громадських засадах, бо головною об'єднуючою засадою української діаспори Канади $\epsilon$ 
збереження національної ідентичності. Ці курси розпочались з 3-ма учителями і 18 студентами в 1940-м р., а вже в 1944 р. мали 16 учителів і інструкторів та 81 курсанта [7, с. 6]. 5-місячні курси відбуваються зазвичай взимку та мають три відділи: англійської, української мови та господарчі курси (крою, шиття, вишивки, кулінарії тощо). Крім того, завдяки освітній програмі «Осередку» та благодійній організації «Одноцентовий Фонд» для талановитої української молоді, яка вчиться в цілій низці канадських вишів і вивчає журналістику, славістику або міжнародне право було започатковано стипендію у розмірі \$500. За час свого існування на Вищих освітніх курсах було виховано цілу плеяду майбутніх вчителів, науковців, інженерів, митців, громадських діячів і, загалом, свідомих представників української діаспори Канади.

Важливою сферою діяльності «Осередку» $є$ робота видавництва, яке друкує наукові та художні твори українською та іноземними мовами під серією «Культура й Освіта». Діяльність видавничого центру направлена як на підтримку молодого покоління наших співвітчизників, так і на знайомлення світового співтовариства 3 героїчною історією, духовним світом, багатою культурою та науковим доробком українського народу. Так, завдяки плідній роботі «Осередку» було видано такі роботи, як: «3 піснею через світ. Подорож Української Республіканської Капелі» (1952) Олександра Кошиця, «Давня українська музика і сучасність» (1952) Павла Маценка, «Перші кроки на еміграції» (1955) Ірени Книш та ін.

Отже, українознавча, експозиційна та дослідницька діяльність Центру української культури та освіти «Осередок» має вельми важливе значення для збереження національної ідентичності у Канаді. Саме «Осередок» виступив тією об'єднуючою силою, яка зібрала під одним культурним покровом українців з різними релігійними переконаннями, політичними поглядами і життєвими цінностями у часи воєнного лихоліття, політичної кризи, строкатого економічного стану, квебекського сепаратизму, Холодної війни. Засновниками та меценатами «Осередку» виступили визначні українські діячі - члени УНО, КУК, НТШ, зокрема митці: О. Кошиць, Т. Кошиць, П. Маценко, М. Мандрика, Т. Павличенко; політики: П. Юзик, В. Коссар; науковці: М. Марунчак, Я. Рудницький, Т. Приймак та ін. За останні 76 років своєї роботи «Осередок» став беззаперечним гарантом колективної пам'яті та зберігачем традицій українського народу. Навіть будинок організації, у минулому Дім Біблійного товариства, має велику духовну силу, яка сприяє благородній соціокультурній місії. Надзвичайно вражає багатогранність діяльності «Осередку», яка охоплює архівну, бібліотечну, музейну, освітню та видавничу роботу. Архів організації має найбільшу в Канаді колекцію документів, мемуарів, світлин, карт, яка охоплює період XVI-XX ст. Цінними є документи та спогади I. М. Боберського, Є. М. Коновальця, подружжя Кошиців, а також пам'ятка XVIII ст. - Iрмолой Георгія Тяпецького. «Осередок» має дуже багаті бібліотечні фонди, які становлять понад 40 тис. томів і 10 тис. періодичних видань. Серед рідкісних книг можна виділити Номоканон XVII ст. Обсяг колекції музею центру складає 8 тис. експонатів, що охоплює предмети декоративно-ужиткового мистецтва, музичні інструменти, церковне начиння, персональні речі. В колекціях мистецької галереї можна побачити полотна понад 30 українських художників від реалізму до авангардизму. При «Осередку» діють Вищі освітні курси, які виховали чимало видатних українців свідомих громадян Канади. Видавнича діяльність центру сприяла не тільки розвитку науки та мистецтва, але і познайомила весь світ з багатою українською культурою. Отже, Центр української культури та освіти «Осередок»є взірцем націооб'єднуючої організації, яка гідно тримає жовто-блакитний прапор на теренах світової арени! 


\section{Джерела та література:}

1. Архівна україніка в Канаді : довідник / упоряд.: І. Б. Матяш, Р. В. Романовський, М. В. Ковтун. - К. : Держкомархів України, 2010. - 882 с.

2. Джус О. В. Теорія і практика професійної підготовки молоді у закладах освіти української діаспори (XX ст.) : дис. ... доктора пед. наук : 13.00.01 / Джус Оксана Володимирівна; Східноукраїнський національний університет ім. В. Даля. - Київ, 2020. -475 с.

3. Марунчак М. Г. Студії історії українців Канади. Розвідки та документи до міжвоєнноі доби / М. Г. Марунчак. - Вінніпег : Trident Press, 1980. - Т. 5. - 215 с.

4. Матяш I. Б. Архівна та рукописна україніка в Канаді / I. Б. Матяш // Український археографічний щорічник / ред. П. С. Сохань. - К. : Бізнесполіграф, 2007. - Вип. 12. - С. 37-82.

5. Матяш І. Б. Осередок української культури і освіти // Енциклопедія історії України : у 10 т. / редкол.: В. А. Смолій (голова) та ін. - К. : Наукова думка, 2010. - Т. 7 : Мл-О. - С. 649.

6. Матяш I. Б. Український дипломатичний архів як джерело дослідження історії консульської служби / І. Б. Матяш // Рукописна та книжкова спадщина України / ред. Л. А. Дубровіна. - К. : Нац. б-ка України ім. В. І. Вернадського, 2016. - Вип. 20. - С. 252-266. 7. Осередок культури й освіти. Цілі і завдання / упоряд. В. Коссар, Т. К. Павличенко. Вінніпег : The Ukrainian National Publishing, 1945. - 23 c.

8. Осередок української культури й освіти в Вінніпегу // Українська мала енциклопедія : 16 кн. : у 8 т. / ред. Є. Д. Онацький. - Буенос-Айрес : Дзвін, 1962. - Т. 5, кн. Х : Літ. Ол-Пер. - C. 1250 .

9. Павличенко Т. К. Рух Національної Єдності. 3 приводу Ювілейної Конференції УНО Канади / Т. К. Павличенко. - Вінніпег : Новий шлях, 1952. - 31 с.

10. Солонська Н. Г. Книжкова комунікація українських іммігрантів у Канаді як засіб національного спілкування / Н. Г. Солонська // Українознавчий альманах / ред. С. В. Руденко. - К. : Міленіум, 2016. - Вип. 19. - С. 152-155.

11. Солонська Н. Г. Українська канадіана : анотований покажчик видань 3 фонду Національної бібліотеки України ім. В. І. Вернадського / Н. Г. Солонська, Г. О. Борисович, наук. ред. Г. І. Ковальчук. - К. : Нац. б-ка України ім. В. І. Вернадського, 2017. - 176 с.

12. Prymak T. M. A visit to Oseredok: The Ukrainian museum and library in Winnipeg / T. M. Prymak. - Toronto : University of Toronto, 2018. - $16 \mathrm{p}$.

13. Ukrainian Cultural and Educational Centre 1944-1954 / Ed. T. O. Koshytz, P. P. Macenko. Winnipeg : The Ukrainian National Publishing, 1954. - 14 p.

\section{References:}

1. Matyash, I. B., Romanovs'kyy, R. V., and Kovtun, M. V. comps., 2010. Arkhivna ukrayinika v Kanadi: dovidnyk. Kyiv: Derzhkomarkhiv Ukrayiny. [in Ukrainian].

2. Dzhus, O. V., 2020. Teoriya i praktyka profesiynoyi pidhotovky molodi u zakladakh osvity ukrayins'koyi diaspory (XX st.) [Theory and practice of vocational training of youth in educational institutions of the Ukrainian diaspora $\left(20^{\text {th }}\right.$ century)]. D.Ed. Volodymyr Dahl East Ukrainian National University. [in Ukrainian].

3. Marunchak, M. H., 1980. Studiyi istoriyi ukrayintsiv Kanady. Rozvidky ta dokumenty do mizhvoyennoi doby, Vol. 5. Winnipeg: Trident Press. [in Canadian].

4. Matyash, I. B., 2007. Arkhivna ta rukopysna ukrayinika v Kanadi [Archival and manuscript Ukrainian in Canada]. In: Sokhan, P. S. ed., 2007. Ukrayins'kyy arkheohrafichnyy shchorichnykUkrainian Archaeographic Yearbook, 12, pp. 37-82. [in Ukrainian].

5. Matyash, I. B., 2010. Oseredok ukrayins'koyi kul'tury i osvity [Ukrainian Cultural and Educational Centre]. In: Smoliy, V. S. ed., 2010. Entsyklopediya istoriyi Ukrayiny: u 10 t. Encyclopedia of the History of Ukraine in 10 vols, Vol. 7. M1.-O. Kyiv: Naukova dumka. p. 649. [in Ukrainian].

6. Matyash, I. B., 2016. Ukrayins'kyy dyplomatychnyy arkhiv yak dzherelo doslidzhennya istoriyi konsul's'koyi sluzhby [Ukrainian diplomatic archive as a source of research on the history of the consular service]. In: Dubrovina, L. A. ed., 2016. Rukopysna ta knyzhkova spadshchyna Ukrayiny- 
Manuscript and book heritage of Ukraine, 20, pp. 252-266. [in Ukrainian].

7. Kossar, V., and Pavlychenko, T. K. comps., 1945. Oseredok kul'tury y osvity. Tsili i zavdannya. Winnipeg: The Ukrainian National Publishing. [in Canadian].

8. Onats'kyy, Ye. D. ed., 1962. Oseredok ukrayins'koyi kul'tury i osvity v Winnipegu [Ukrainian Culture and Education Center in Winnipeg] Ukrayins'ka mala entsyklopediya: $16 \mathrm{kn} .:$ u 8 t. Ukrainian small encyclopedia: 16 books.: in 8 vol., Vol. 5, book 10, Ol-Per. Buenos-Aires: Dzvin. p. 1250. [in Argentine].

9. Pavlychenko, T. K., 1952. Rukh Natsional'noyi Yednosti. Z pryvodu Yuvileynoyi Konferentsiyi UNO Kanady. Winnipeg: Novyy shlyakh. [in Canadian].

10. Solons'ka, N. H., 2016. Knyzhkova komunikatsiya ukrayins'kykh immihrantiv u Kanadi yak zasib natsional'noho spilkuvannya [Book communication of Ukrainian immigrants in Canada as a means of national communication] In: Rudenko, S. V. ed. Ukrayinoznavchyy al'manakh Ukrainian Studies Almanac, 19, pp. 152-155. [in Ukrainian].

11. Solons'ka, N. H., Borysovych, H. O., and Koval'chuk, H. I., 2017. Ukrayins'ka kanadiana: anotovanyy pokazhchyk vydan' z fondu Natsional'noyi biblioteky Ukrayiny im. V. I. Vernads'koho. Kyiv: Nats. b-ka Ukrayiny im. V. I. Vernads'koho. [in Ukrainian].

12. Prymak, T. M., 2018. A visit to Oseredok: The Ukrainian museum and library in Winnipeg. Toronto: University of Toronto. [in Canadian].

13. Koshytz, T. O. ed., 1954. Ukrainian Cultural and Educational Centre 1944-1954. Winnipeg: The Ukrainian National Publishing. [in Canadian].

Отримано: 07.11.2020 p. 